\title{
Macromolecular confinement of therapeutic protein in polymeric particles for controlled release: insulin as a case study
}

\author{
Luiz Henrique Guerreiro, ${ }^{1,2}$, Daniel da Silva ${ }^{3}$, Wendell Girard-Dias ${ }^{4}$, Camile Moreira Mascarenhas ${ }^{1}$, \\ Kildare Miranda ${ }^{4}$, Mauro Sola-Penna ${ }^{3}$, Eduardo Ricci Júnior ${ }^{5}$, Luís Mauricio Trambaioli da Rocha \\ e $\operatorname{Lima}^{1^{*}}$
}

\begin{abstract}
${ }^{1}$ Laboratory for Pharmaceutical Biotechnology, CCS, Federal University of Rio de Janeiro, UFRJ, Rio de Janeiro, RJ, Brazil. ${ }^{2}$ Department of Pharmaceutical Sciences, Institute of Biological and Health Sciences, Rural Federal University of Rio de Janeiro, UFRRJ, Seropédica, RJ, Brazil, ${ }^{3}$ Laboratory for Enzymology and Metabolism Control, LabECoM, Federal University of Rio de Janeiro, UFRJ, Rio de Janeiro, RJ, Brazil, ${ }^{4}$ Laboratory for Cell Supramolecular Structure Prof. Hertha Meyer, IBCCF, Federal University of Rio de Janeiro, UFRJ, Rio de Janeiro, RJ, Brazil, ${ }^{5}$ Laboratory for Galenic Pharmaceutical Technology, LADEG, Federal University of Rio de Janeiro, UFRJ, Rio de Janeiro, RJ, Brazil
\end{abstract}

\begin{abstract}
Sustained release systems for therapeutic proteins have been widely studied targeting to improve the action of these drugs. Molecular entrapping of proteins is particularly challenging due to their conformational instability. We have developed a micro-structured poly-epsilon-caprolactone (PCL) particle system loaded with human insulin using a simple double-emulsion w/o/w method followed by solvent evaporation method. This formulation is comprised by spheric-shaped microparticles with average size of 10 micrometers. In vitro release showed a biphasic behavior such as a rapid release with about $50 \%$ of drug delivered within 2 hours and a sustained phase for up to $48 \mathrm{~h}$. The subcutaneous administration of microencapsulated insulin showed a biphasic effect on glycemia in streptozotocin-induced diabetic mice, compatible with short and intermediate-acting behaviors, with first transition peak at about $2 \mathrm{~h}$ and the second phase exerting effect for up to $48 \mathrm{~h}$ after s.c. administration. This study reveals that a simplified double-emulsion system results in biocompatible human-insulin-loaded PCL microparticles that might be used for further development of optimized sustained release formulations of insulin to be used in the restoration of hormonal levels.
\end{abstract}

Uniterms: Human insulin/study. Microparticles. Poly- $\varepsilon$-caprolactone. Therapeutic proteins/study/action. Proteins/molecular entrapping.

\section{INTRODUCTION}

The World Health Organization (WHO) estimates that more than 180 million people worldwide are diabetic and this health problem is responsible for $5 \%$ of all deaths each year (Wild et al., 2004; Roglic et al., 2005). The Diabetes Mellitus (DM) is a group of chronic diseases which occur when pancreas does not produce enough insulin or there is a resistance to this hormone, and in some cases are observed production and action of insulin deficient condition increasing blood sugar level and risk of microvascular damage (retinopathy, nephropathy and

\footnotetext{
*Correspondence: L. M. T. R. Lima. Laboratory for Pharmaceutical Biotechnology. Federal University of Rio de Janeiro - UFRJ. CCS, Bss34, Ilha do Fundão - 21941-590 - Rio de Janeiro - RJ, Brasil. Phone/Fax: (+55-21) 2562-6639. E-mail:1ml@ufrj.br, luizguerreiro@ufrrj.br
}

neuropathy) (American Diabetes Association, 2013; WHO, 2008).

Insulin is a polypeptide hormone synthesized in the $\beta$-cells of Langerhans islets in the pancreas. This hormone is composed of two chains linked by disulfide bonds, chain $\mathbf{A}$ with 21 amino acids and chain $\mathbf{B}$ with 30 amino acids. Hormone replacement therapy using exogenous insulin is necessary for patients with DM, especially for patients with Type 1 DM. However, a perfect glycemic control is still a difficult task despite the number of insulin formulations in market with different pharmacokinetics characteristics (Veiseh et al., 2015).

Therefore, the developments of pharmaceutical compositions, which reduce the number of insulin shots, are needed for both better glycemic control and for improving patient's quality of life. There are many 
approaches for sustained release development, but not all methods are applicable to biopharmaceuticals due to its high lability. The most common methods used in pharmaceutical biotechnology are: nano and microencapsulation, using solid matrixes as PLGA, PLA and PCL; liposomes, which uses liquid matrixes such as phosphatidylcholine; derivatization with polymers, such as polyethylene glycol; the use of biocompatible gels, such as Pluronic F27; or the combination of two or more of these techniques (Calceti et al., 2004; Almeida, Souto, 2007; Liu et al., 2007a; Liu et al., 2007b; Huynh et al., 2009; Rastogi, Anand, Koul, 2009).

Several approaches have been proposed to make an insulin sustained release system but so far no medicine containing micro or nanoencapsuladed insulin has been available commercially. In our work, we ought to develop a system containing insulin confined into polymeric microparticles, which could be used for the sustained release of insulin in vivo. In this study, the PCL was the polymer of choice because it is of lowcost, biocompatible, biodegradable and it has been using in various formulations (Benoit, Baras, Gillard, 1999; Lamprecht et al., 1999; Sinha et al., 2004; Hasan et al., 2007; Wang et al., 2007). We report here a simple method based on double emulsification followed by simple vacuum solvent extraction for the production of PCL microparticles comprising bioactive insulin.

\section{MATERIAL AND METHODS}

\section{Chemicals}

Poly- $\varepsilon$-caprolactone (MW 65,000 Da), poly (vinyl alcohol) (87-89\% hydrolyzed, average MW 31,000$50,000 \mathrm{Da}$ ) and streptozotocin (STZ) were obtained from Sigma-Aldrich (St. Louis, USA). Biosynthetic human insulin Humulin-R ${ }^{\circledR}$ (recombinant human insulin, metacresol, gycerol and water for injection) was obtained from local drugstore and stored as directed until use. Type I water was used throughout. Other reagents were from analytical grade.

\section{Preparation of insulin microparticles}

PCL microparticles were prepared by a modified double-emulsion (water-in-oil-in-water) solvent evaporation/extraction technique (Benoit, Baras, Gillard, 1999; Damgé et al., 2009). Briefly, $400 \mu \mathrm{L}$ regular-acting human insulin formulation (Humulin $\mathrm{R}^{\circledR}$ ) and $100 \mu \mathrm{L}$ of $5 \%$ PVA aqueous solution was emulsified in a mixed organic solution ( $5 \mathrm{~mL}$ of dichloromethane) containing
PCL (100 mg) by an Ultraturrax $^{\circledR}$ at $10,000 \mathrm{rpm}$ for 1 min. Thereafter, the primary emulsion was poured into 25 $\mathrm{mL}$ of the $1.5 \%$ PVA aqueous solution and homogenized with magnetic stirrer for 10 minutes. The resulting emulsion was stirred with a magnetic stirrer in low speed and the dichloromethane was purged out by evaporation under reduced pressure. The particles were washed out by centrifuging for $15 \mathrm{~min}$ at $14.000 \mathrm{xg}$ at $4{ }^{\circ} \mathrm{C}$ and resuspending the particles in $1.5 \%$ PVA aqueous solution for three times.

\section{Particle size distribution and morphology}

Particle size distribution (mean diameter and polydispersity index) of microparticles was determined at $25^{\circ} \mathrm{C}$ by dynamic laser light scattering (Shimadzu SALD-2201, Shimadzu, Japan) over the range of 0.005 to $1,000 \mu \mathrm{m}$, in a $1.0 \mathrm{~cm}$ quartz cell after proper dilution in water. Particle distribution and morphology were also evaluated by conventional optical microscopy with particles dispersed in water over siliconized glass slide. Several viewing fields were registered and particle size measurement was performed using ImageJ software (version 1.42, National Institutes of Health, USA), computed from a set comprising a total of 10,000 particles randomly selected. Results are representative of measurements performed with three microparticles preparations $(n=3)$, to confirm mean diameter obtained by DLS (data not show).

\section{Morphological analysis by scanning electron microscopy (SEM)}

The morphological analysis of the resulting microparticles was performed using Scanning Electron Microscopy (SEM). In brief, a suspension of the microparticles was dispersed onto a glass slide and plunge frozen in liquid nitrogen and freeze-dried. Dried samples were then coated with $10 \mathrm{~nm}$ gold layer at room temperature and observed in a JEOL6340 Field Emission SEM operating at $5.0 \mathrm{kV}$.

\section{Insulin encapsulation efficiency and yield}

The total amount of insulin entrapped within PCL microparticles was accessed by measuring the amount of nonentrapped protein in the external aqueous solution recovered after centrifugation and washing of the microparticles. Protein loading efficiency was expressed as the percentage of insulin entrapped with respect to the theoretical value (Equation 1). The yield was calculated 
using the particles after washing and lyophilization. The value was the percentage of mass recovered as follow (Equation 2). Protein was quantified with the Bradford method (Bradford, 1976), using insulin for standard curve. Insulin for the standard curve was quantified by absorbance measurements at $280 \mathrm{~nm}$ (Gill, Von Hippel, 1989).

Efficiency Load $=\frac{\left(\begin{array}{c}\text { Total } \\ \text { Insulin }\end{array}\right)-\left(\begin{array}{c}\text { Insulin quantified in } \\ \text { the aqueous phase }\end{array}\right)}{\text { Total Insulin }} \times 100$ Eq. 1

Yield $=\frac{\text { Mass after lyophilization } \times 100}{\sum \text { of non-volatile components }}$

Eq. 2

\section{In vitro kinetic release assays}

The washed microparticles were dispersed in $20 \mathrm{~mL}$ of PBS pH 7.4 and $0.02 \% \mathrm{NaN}_{3}$, distributed in centrifugal microtubes containing $1.0 \mathrm{~mL}$ of the microparticles suspension each and incubated statically at $37^{\circ} \mathrm{C}$ (Guerreiro et al., 2012). This assay was performed in sink conditions with the theoretical maximum insulin concentration below $0.05 \mathrm{mg} / \mathrm{mL}$. At varying time intervals, samples were centrifuged for 30 minutes at $20,000 \mathrm{~g}$ at $4{ }^{\circ} \mathrm{C}$, and the supernatant were assayed for total protein released using the Comassie colorimetric method (Bradford, 1976).

\section{Pharmacological evaluation in vivo}

Pharmacological evaluation of the hypoglycemic effect of insulin was performed as previously reported (Finotelli et al., 2010) with Swiss male mice (8 weeks; $27 \mathrm{~g} \pm 1 \mathrm{~g}$ ), housed in a temperature-controlled room with a $12 \mathrm{~h}$ light-dark cycle and given free access to water and normal chows. Type 1 diabetes was induced by one intraperitoneal (ip.) injection of STZ $(200 \mathrm{mg} /$ $\mathrm{kg}$ ) dissolved in fresh citrate buffer (100 mM, pH 4.5). After STZ administration (5 days), blood was drawn from mice by tail snip and glucose levels were measured using a glucometer (Accu-Chek ${ }^{\circledR}$ Active - Roche). After STZ treatment, animals, which show more than $300 \mathrm{mg} /$ $\mathrm{dL}$, were considered diabetics. Mice were separated in three groups: i) control: receiving placebo MP $(n=3)$; ii) receiving soluble regular human insulin $(\mathrm{n}=5 ; 5 \mathrm{U} / \mathrm{kg})$; and iii) test: receiving insulin-loaded microparticles $(\mathrm{n}=5$; $10 \mathrm{U} / \mathrm{kg}$ ). Food was suspended $4 \mathrm{~h}$ before the experiments, and all mice were fasted throughout the experiments and kept at $22 \pm 2{ }^{\circ} \mathrm{C}$. Mice were administrated by subcutaneous route (s.c.) using a standard 29 gauge needle $\left(\mathrm{BD}^{\mathrm{TM}}\right)$. The glycemia was monitored following the recommendations of the Mouse Metabolic Phenotyping Center (MMPC) Consortium from the National Institutes of Health (NIH) (Ayala et al., 2010) by using whole blood from the tail tip of conscious, unrestrained mice using pre-calibrated point-ofcare glucometers (Accu-Chek ${ }^{\circledR}$ Active, Roche Diagnostics, Germany; Serial No GN08146937) before injection and at repeated intervals after administration. The pharmacological evaluation over a prolonged time was not possible due to the limitations in the extent of animal starvation. This protocol was approved by the Institutional Bioethics Committee on Animal Care and Experimentation at UFRJ.

\section{Data analysis}

Data analysis of insulin release in vitro and insulin effects over plasma glycemia was performed to obtain the rates by non-linear least squares fitting, using double exponential equation as follow:

$\mathrm{C}_{\mathrm{t}}=\mathrm{C}_{0}+\mathrm{A}_{1} * \exp \left(-\mathrm{k}_{1} * \mathrm{t}\right)+\mathrm{A}_{2} * \exp \left(-\mathrm{k}_{2} * \mathrm{t}\right)$ Eq. 3

where $\mathbf{C}_{t}$ and $\mathbf{C}_{0}$ are the concentration of insulin or glucose at time $\mathbf{t}$ and zero, respectively; $\mathbf{A}$ and $\mathbf{k}$ are the event amplitude (concentration changes) and kinetic rates for phases 1 and 2, respectively.

\section{Statistical analysis}

Statistical analysis was performed with the t-test. The significance of the differences in the pharmacological evaluation was calculated and values of $p<0.05$ were considered to be significant. The analyses were performed using the SigmaStat as implemented in SigmaPlot 11 (Systat Software Inc).

\section{RESULTS AND DISCUSSION}

\section{Characterization of the microparticles}

We have prepared insulin-loaded microparticles using PCL and a simple w/o/w emulsification system. Our preparation yielded microparticles with average size of $9.8 \pm 0.6 \mu \mathrm{m}$, as evaluated by dynamic light scattering measurements (Figure 1).

Optical microscopy imaging shows uniform, individualized spherical microparticles, with average sizes of $10.8 \pm 4.6 \mu \mathrm{m}$ (Figure 2 ), in agreement with DLS measurements. The particles have micrometric sizes, as demonstrated by the morphological evidences shown in the optical microscopy, because this data reveal compartmentalized microparticles. The insulin concentration in supernatant of the washing pool indicates efficiency of $64.5 \pm 6.8 \%$. After freeze-dried samples 


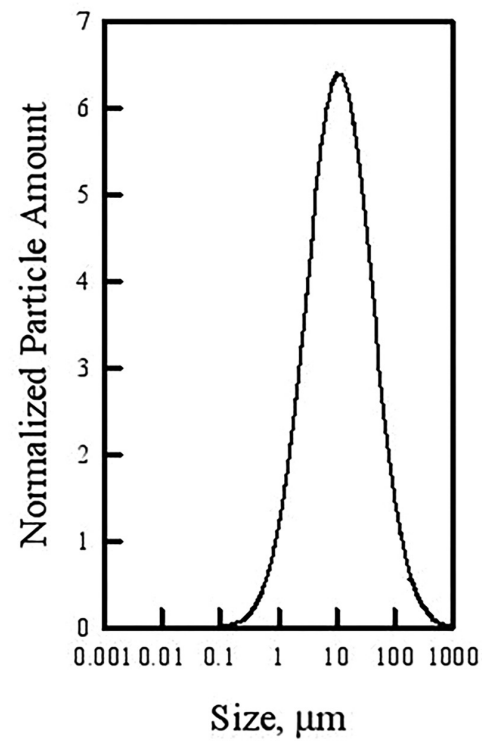

FIGURE 1 - Insulin-PCL particles size distribution. Particles were evaluated by DLS after dispersion in water. Mean particle diameter $=9.8 \pm 0.57 \mu \mathrm{m}$. Details in the Material and Methods section.

were weighed and yield calculated for the process was $88.4 \pm 4.2 \%$.

\section{In vitro release}

Figure 3 shows the release kinetics in vitro for microencapsulated insulin formulation. In this result was possible to observe a burst effect with about $50 \%$ of insulin being released in the first 2 hours. The kinetics of in vitro release was shown biphasic with an initial burst
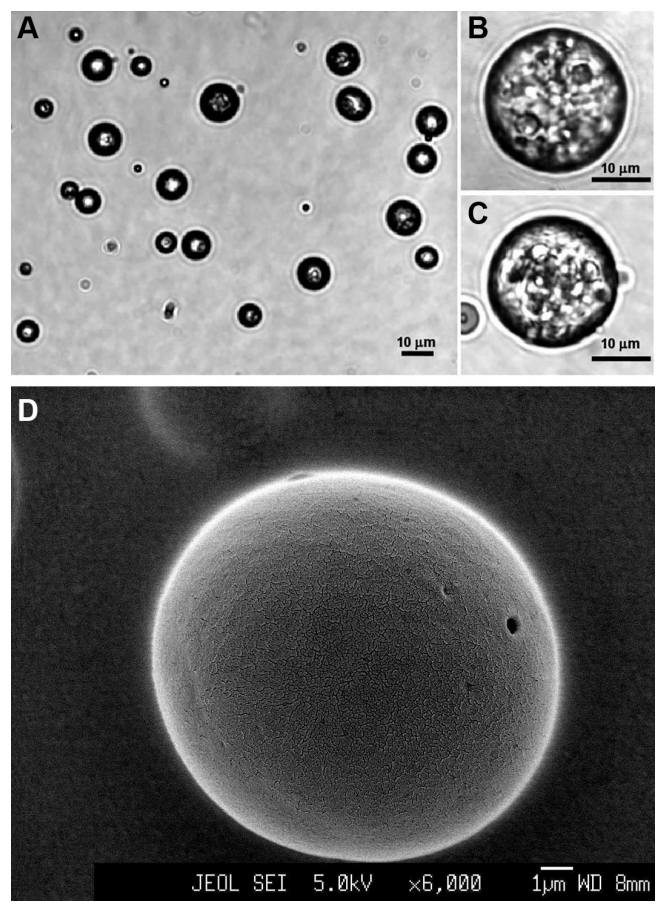

FIGURE 2 - Morphological characterization of insulin-loaded PCL microparticles. Optical microscopy (A, B and C). Scanning Electron Microscopy (D). Details in the Material and Methods section.

effect in the first $2 \mathrm{~h}$ and a second phase of release, slower, approximately four days.

\section{In vivo release}

Were performed in vivo experiments using diabetic mice to evaluate the activity of insulin released over time.
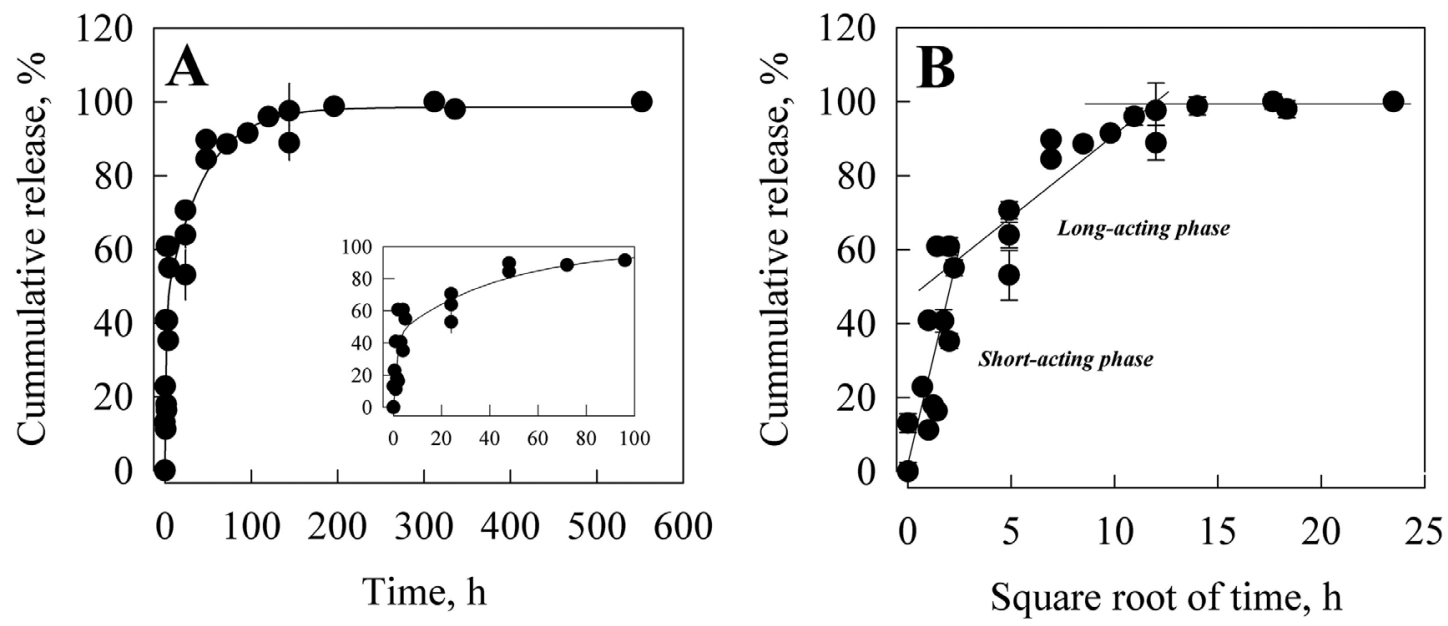

FIGURE 3 - Kinetics of human insulin release from PCL microparticles. A) Cumulative release in a linear time scale. Inset: detail view of kinetics at initial range. Solid lines correspond to best fitting using Equation 1. Results are depicted in Table I and II. B) Higuchi plot. Solid lines are solely to depict human insulin releasing phases. Data represents measurements in triplicate from kinetics performed with three microparticles batches. 
TABLE I - Kinetic parameters from the in vitro release of human insulin from the PCL microparticles. Parameters were obtained from data in Figure 3

\begin{tabular}{lc}
\hline & MP: insulin \\
\hline Rate constant $\mathrm{k}_{1}$ & $0.76 \pm 0.39 \mathrm{~h}^{-1}$ \\
Rate constant $\mathrm{k}_{2}$ & $0.023 \pm 0.009 \mathrm{~h}^{-1}$ \\
Amplitude $\mathrm{A}_{1}$ & $44.9 \pm 9.9 \%$ \\
Amplitude $\mathrm{A}_{2}$ & $55.6 \pm 9.8 \%$ \\
\hline
\end{tabular}

TABLE II - Kinetic parameters from the pharmacological evaluation of the glycemic effect of MP-insulin. Parameters were obtained from data in Figure 3

\begin{tabular}{lcc}
\hline & MP: insulin & Soluble insulin \\
\hline Rate constant $\mathrm{k}_{1}$ & $2.58 \mathrm{~h}^{-1}$ & $2.59 \mathrm{~h}^{-1}$ \\
Rate constant $\mathrm{k}_{2}$ & $0.047 \mathrm{~h}^{-1}$ & $0.18 \mathrm{~h}^{-1}$ \\
\hline
\end{tabular}

Figure 4 shows that the formulation was able to reduce blood glucose levels of mice for 24 hours significantly different from that observed in the group of mice that received the commercial formulation of insulin $\mathrm{R}$.

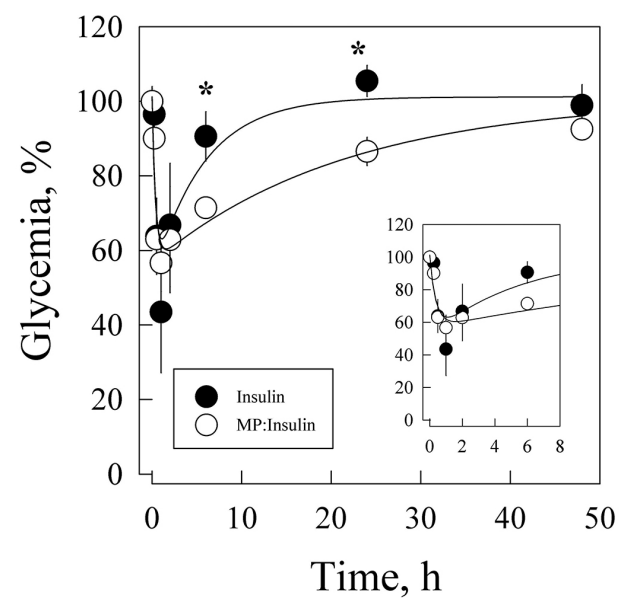

FIGURE 4 - Pharmacological evaluation of MP-insulin in diabetic mices. Streptozotocin-induced mices were administrated s.c. with regular human insulin solution (closed symbols; $n=5$ ) or insulin-loaded PCL microparticles (open symbols, $n=5$ ) and the glucose level was evaluated. Symbols represent mean $\pm \mathrm{SD}$. Inset: glycemia change at initial time range. $* \mathrm{p}<0.05$ (t-test). Lines are non-linear regression with Eq. 1. Details in the Material and Methods section.

The development of formulations with insulin sustained release systems have been previously reported in the literature (Liu et al., 2007a, 2007b; Damgé et al., 2009; Han et al., 2009; Huynh et al., 2009; Kim et al., 2009;
Klingler, Müller, Steckel, 2009; Ungaro et al., 2009). Almost recent studies use nanoparticles to increase the insulin effect. However, it was reported the nanoparticles may move from injection sites to the blood vessels leading to the capture of these by the liver and spleen and consequent loss of action (De Jong, Borm, 2008). Despite of all efforts, only a few systems for insulin pulmonary delivery reached the market, and one of these was removed after showed some side effects such as the formation of amyloid deposits in the lungs of patients (Lasagna-Reeves et al., 2010). The encapsulation efficiency of $64.5 \%$ is lower than the expected for the method of double-emulsion and solvent extraction using emulsion type $\mathrm{w} / \mathrm{o} / \mathrm{w}$ since other authors using a similar methodology obtained higher efficiency (Damgé, Maincent, Ubrich, 2007; Peng et al., 2012). However, the encapsulation efficiency per se is not an exclusion criterion in the development pipeline, once assured proper pharmacological profile and maintenance of physical-chemical stability of the peptide in the formulation. In preliminary studies we tried to use dialyzed insulin, but the formulations without excipients (metacreol, glycerol etc.) did not show satisfactory data (data not shown) indicating that our method, to keep these excipients, was able to better preserve this hormone.

Regarding the release profile in vitro was observed that the preparation have a release kinetic over three days, and the first day of a release of most of the material. The kinetics of release stresses of the first 2 hours was also observed in experiments using diabetic mice, and the hypoglycemic effect of the formulation was more than 24 hours of experiment. Interestingly, despite having a release kinetics in vitro faster than those described by other authors working with similar formulations developed here, our in vivo release data shows a long-lasting action, suggesting a more effective stabilization. We believe that this stability is due in part because of the use of preformulated regularacting insulin from commercial source (insulin and adjuvants) to prepare the microparticles, since experiments using non-formulated insulin (without excipients) did not result in satisfactory encapsulation efficiency as well as in an erratic release profiles (data not shown). These data demonstrate that the encapsulation efficiency and quality of the resulting product for protein products in a biologically active form is dependent of the formulation process, including stabilization of the proteic active pharmaceutical ingredient. In fact, glycerol and metacresol are important excipients for the stability of commercial insulin formulations.

Glycerol is commonly used as an osmotic agent, but this adjuvant also can prevent the formation of high-molecular-weight protein and aggregates in the 
compositions with insulin (Brange, Langkjaer, 1992). Phenol derivatives are used because of their antimicrobial effects as preservatives, but they are capable of reducing deamidation processes, which are the main route of degradation of insulins during storage (Whittingham et al., 1998). In additional, phenolic derivates can stabilize interactions between monomers and insulin dimers and hexameric conformation (Crommelin, Sindelar, Meibohm, 2008). In this work we have not investigated the effects of the excipients alone since both are important for the stability of the compositions because they act in different ways, but further studies may be carried out in order to evaluate the stability of the insulins in polymer matrices in the presence of pharmaceutical adjuvants.

Another important finding in our study is the reduction in blood glucose in animals treated in the first points of the test. Thus, although high dose of 10 IU versus 5 IU in control group, the microencapsulated formulation was able to prevent episodes of hypoglycemia in diabetic mice, a major side effect of commercial insulin formulations. Another important application of this system might be the prevention of amyloid insulin formation, since studies reporting insulin aggregates at the application site are frequent (Swift et al., 2002; Nagase, 2009; Lasagna-Reeves et al., 2010). In contrast, polymer particles similar to those developed in this work have been used to inhibit markedly amyloidogenic proteins (Cabaleiro-Lago et al., 2010; Guerreiro et al., 2012).

\section{CONCLUSION}

Despite all efforts for developing intelligent drug delivery systems, the characteristics of complex peptides, like insulin, added to the specific needs for diabetes treatments make this a challenge that seems to have a distant end. Our work has shown a simple and scalable way to produce longer lasting insulin formulation with no hypoglycemic effect in the tested dose, which can improve the quality of the therapeutic intervention.

\section{ABBREVIATIONS}

PCL, poli- $\varepsilon$-caprolactone; MP, microparticles; w/o/w, water-in-oil-in-water emulsion; s.c., subcutaneous; STZ, streptozotocin; PVA, poly(vinil alcohol).

\section{ACKNOWLEDGEMENTS}

We would like to thank Mrt. Luiz Carlos Coimbra (S/SUBG/CIN/CAL-Dept. Suprimentos, Prefeitura do Rio de Janeiro) for the donation of the human insulin.
This research was supported by the Coordenação de Aperfeiçoamento de Pessoal de Nível Superior (CAPES); Conselho Nacional de Desenvolvimento Científico e Tecnológico (CNPq), INCT-CNPq; Fundação de Amparo à Pesquisa do Estado do Rio de Janeiro Carlos Chagas Filho (FAPERJ). Funding agencies had no role in study design, data collection or analysis.

\section{CONFLICT OF INTEREST}

"Prof. Luis Mauricio T. R. Lima, Prof. Luiz H. Guerreiro, Prof. Eduardo Ricci-Junior and Camila Moreira Mascarenhas are applicant of a patent regarding insulin controlled release. "Sistema polimérico de confinamento de insulina, processo e uso de dito sistema". Camile Moreira Mascarenhas, Eduardo Ricci Júnior, Luís Mauricio T. R. Lima, Luiz Henrique Guerreiro Rosado. PI 1103164-6 A2.

\section{REFERENCES}

ALMEIDA, A.J.; SOUTO, E. Solid lipid nanoparticles as a drug delivery system for peptides and proteins. Adv. Drug Deliver. Rev., v.59, n.6, p.478-490, 2007.

AMERICAN DIABETES ASSOCIATION. Diagnosis and classification of Diabetes Mellitus. Diabetes Care, Suppl., p.S67-S74, 2013.

AYALA, J.E.; SAMUEL, V.T.; MORTON, G.J.; OBICI, S.; CRONIGER, C.M.; SHULMAN, G.I.; WASSERMAN, D.H.; MCGUINNESS, O.P. Standard operating procedures for describing and performing metabolic tests of glucose homeostasis in mice. Disease Models \& Mech., v.3, n.9-10, p.525-534, 2010.

BENOIT, M.-A.; BARAS, B.; GILLARD, J. Preparation and characterization of protein-loaded poly( $\varepsilon$-caprolactone) microparticles for oral vaccine delivery. Int. J. of Pharm., v.184, n.1, p.73-84, 1999.

BRADFORD, M.M. A rapid and sensitive method for the quantitation of microgram quantities of protein utilizing the principle of protein-dye binding. Anal. Biochem., v.72, n.1-2, p.248-254, 1976.

BRANGE, J.; LANGKJAER, L. Chemical stability of insulin. 3. Influence of excipients, formulation, and $\mathrm{pH}$. Acta Pharm. Nordica, v.4, n.3, p.149-158, 1992. 
CABALEIRO-LAGO, C.; LYNCH, I.; DAWSON, K.A.; LINSE, S. Inhibition of IAPP and IAPP(20-29) Fibrillation by Polymeric Nanoparticles. Langmuir, v.26, n.5, p.34533461, 2010.

CALCETI, P.; SALMASO, S.; WALKER, G.; BERNKOPSCHNÜRCH, A. Development and in vivo evaluation of an oral insulin-PEG delivery system. Eur. J. Pharm. Sci., v.22, n.4, p.315-323, 2004.

CROMMELIN, D.J.A.; SINDELAR, R.D.; MEIBOHM, B. (Eds.). Pharmaceutical biotechnology: fundamentals and applications. 3.ed. New York: Informa Healthcare, 2008. 466 .

DAMGÉ, C.; MAINCENT, P.; UBRICH, N. Oral delivery of insulin associated to polymeric nanoparticles in diabetic rats. J. Control. Release, v.117, n.2, p.163-170, 2007.

DAMGÉ, C.; SOCHA, M.; UBRICH, N.; MAINCENT, P. Poly( $\varepsilon$-caprolactone)/eudragit nanoparticles for oral delivery of aspart-insulin in the treatment of diabetes. $J$. Pharm. Sci., v.99, n.2, p.879-889, 2009.

DE JONG, W.H.; BORM, P.J. Drug delivery and nanoparticles: Applications and hazards. Int. J. Nanomed., v.3, n.2, p.133149, 2008.

FINOTELLI, P.V.; DA SILVA, D.; SOLA-PENNA, M.; ROSSI, A.M.; FARINA, M.; ANDRADE, L.R.; TAKEUCHI, A.Y.; ROCHA-LEÃO, M.H. Microcapsules of alginate/chitosan containing magnetic nanoparticles for controlled release of insulin. Colloid Surf. B, v.81, n.1, p.206-211, 2010.

GILL, S.C.; VON HIPPEL, P.H. Calculation of protein extinction coefficients from amino acid sequence data. Anal. Biochem., v.182, n.2, p.319-326, 1989.

GUERREIRO, L.H.; DA SILVA, D.; RICCI-JUNIOR, E.; GIRARD-DIAS, W.; MASCARENHAS, C.M.; SOLAPENNA, M.; MIRANDA, K.; LIMA, L.M.T.R. Polymeric particles for the controlled release of human amylin. Colloid Surf. B, v.94, p.101-106, 2012.

HAN, Y.; TIAN, H.; HE, P.; CHEN, X.; JING, X. Insulin nanoparticle preparation and encapsulation into poly(lacticco-glycolic acid) microspheres by using an anhydrous system. Int. J. Pharm., v.378, n.1-2, p.159-166, 2009.
HASAN, A.S.; SOCHA, M.; LAMPRECHT, A.; GHAZOUANI, F.E.; SAPIN, A.; HOFFMAN, M.; MAINCENT, P.; UBRICH, N. Effect of the microencapsulation of nanoparticles on the reduction of burst release. Int. J. Pharm., v.344, n.1-2, p.53-61, 2007.

HUYNH, D.P.; IM, G.J.; CHAE, S.Y.; LEE, K.C.; LEE, D.S. Controlled release of insulin from $\mathrm{pH} /$ temperature-sensitive injectable pentablock copolymer hydrogel. J. Control. Release, v.137, n.1, p.20-24, 2009.

KIM, B.S.; OH, J.M.; HYUN, H.; KIM, K.S.; LEE, S.H.; KIM, Y.H.; PARK, K.; LEE, H.B.; KIM, M.S. Insulin-loaded microcapsules for in vivo delivery. Mol. Pharm., v.6, n.2, p.353-365, 2009.

KLINGLER, C.; MÜLLER, B.W.; STECKEL, H. Insulinmicro- and nanoparticles for pulmonary delivery. Int. J. Pharm., v.377, n.1-2, p.173-179, 2009.

LAMPRECHT, A.; UBRICH, N.; HOMBREIRO PÉREZ, M.; LEHR, C.-M.; HOFFMAN, M.; MAINCENT, P. Biodegradable monodispersed nanoparticles prepared by pressure homogenization-emulsification. Int. J. Pharm., v.184, n.1, p.97-105, 1999.

LASAGNA-REEVES, C.A.; CLOS, A.L.; MIDORO-HIRIUTI, T.; GOLDBLUM, R.M.; JACKSON, G.R.; KAYED, R. Inhaled insulin forms toxic pulmonary amyloid aggregates. Endocrinol., v.151, n.10, p.4717-4724, 2010.

LIU, J.; GONG, T.; WANG, C.; ZHONG, Z.; ZHANG, Z. Solid lipid nanoparticles loaded with insulin by sodium cholatephosphatidylcholine-based mixed micelles: Preparation and characterization. Int. J. Pharm., v.340, n.1-2, p.153-162, 2007a.

LIU, J.; ZHANG, S.M.; CHEN, P.P.; CHENG, L.; ZHOU, W.; TANG, W.X.; CHEN, Z.W.; KE, C.M. Controlled release of insulin from PLGA nanoparticles embedded within PVA hydrogels. J. Mater. Sci-Mater. M, v.18, n.11, p.2205-2210, 2007b.

NAGASE, T. Insulin glargine/insulin lispro Amyloidosis (first report with insulin glargine). Reactions, v.1236, p.24, 2009.

PENG, Q.; ZHANG, Z.-R.; GONG, T.; CHEN, G.-Q.; SUN, X. A rapid-acting, long-acting insulin formulation based on a phospholipid complex loaded $\mathrm{PHBHHx}$ nanoparticles. Biomaterials, v.33, n.5, p.1583-1588, 2012. 
RASTOGI, R.; ANAND, S.; KOUL, V. Evaluation of pharmacological efficacy of "insulin-surfoplex" encapsulated polymer vesicles. Int. J. Pharm., v.373, n.1-2, p.107-115, 2009.

ROGLIC, G.; UNWIN, N.; BENNETT, P.H.; MATHERS, C.; TUOMILEHTO, J.; NAG, S.; CONNOLLY, V.; KING, H. The Burden of Mortality Attributable to Diabetes Realistic estimates for the year 2000. Diabetes Care, v.28, n.9, p.2130-2135, 2005.

SINHA, V.R.; BANSAL, K.; KAUSHIK, R.; KUMRIA, R.; TREHAN, A. Poly- $\epsilon$-caprolactone microspheres and nanospheres: an overview. Int. J. Pharm., v.278, n.1, p.123, 2004.

SWIFT, B.; HAWKINS, P.N.; RICHARDS, C.; GREGORY, R. Examination of insulin injection sites: an unexpected finding of localized Amyloidosis. Diabetic Med., v.19, n.10, p.881-882, 2002.

UNGARO, F.; EMMANUELE DI VILLA BIANCA, R.d'; GIOVINO, C.; MIRO, A.; SORRENTINO, R.; QUAGLIA, F.; LA ROTONDA, M.I. Insulin-loaded PLGA/cyclodextrin large porous particles with improved aerosolization properties: In vivo deposition and hypoglycaemic activity after delivery to rat lungs. J. Control. Release, v.135, n.1, p.25-34, 2009.
VEISEH, O.; TANG, B.C.; WHITEHEAD, K.A.; ANDERSON, D.G.; LANGER, R. Managing diabetes with nanomedicine: challenges and opportunities. Nat. Rev. Drug Discov., v.14, n.1, p.45-57, 2015.

WANG, Y.; CHANG, H.-I.; WERTHEIM, D.F.; JONES, A.S.; JACKSON, C.; COOMBES, A.G.A. Characterisation of the macroporosity of polycaprolactone-based biocomposites and release kinetics for drug delivery. Biomaterials, v.28, n.31, p.4619-4627, 2007.

WHITTINGHAM, J.L.; EDWARDS, D.J.; ANTSON, A.A.; CLARKSON, J.M.; DODSON, G.G. Interactions of phenol and $\mathrm{m}$-cresol in the insulin hexamer, and their effect on the association properties of B28 Pro $\rightarrow$ Asp Insulin analogues. Biochemistry, v.37, n.33, p.11516-11523, 1998.

WILD, S.; ROGLIC, G.; GREEN, A.; SICREE, R. Global estimates of the prevalence of diabetes for 2000 and 2030. Diabetes Care, v.27, p.4-14, 2004.

WORLD HEALTH ORGANIZATION. WHO. Definition and diagnosis of diabetes mellitus and intermediate hyperglycemia. Geneva: World Health Organization, 2008. v.1.

Received for publication on $09^{\text {th }}$ March 2016 Accepted for publication on $19^{\text {th }}$ December 2016 